\title{
Transportation Resilience: A summative review on Definition and Connotation
}

\author{
Meng $\mathrm{CaO}^{1, \mathrm{a}}$ \\ ${ }^{1}$ Department of Construction Management, Tsinghua University, Beijing 10084, China \\ ${ }^{a} \mathrm{~cm} \_1990 @$ foxmail.com
}

Keywords: Resilience; Transportation system; Definition; Attribute.

\begin{abstract}
City transportation systems are always suffering various disruptions from both natural and man-made incidents. These disruptions can incur failure of system and thus bring a more extensive loss to the whole society. The concept of resilience was introduced into transportation system since it concerned about the performance of system under disruptions. Resilience has been initially described as the ability of system to become healthy and strong again after a disruptive event. On transportation resilience, a number of scholars have carried out exploratory researches from different perspectives. However, the definitions and the connotations within it they recommended were quite multifarious. This paper took a summative review of these definitions and connotations and tried to develop an integrated description about what a resilient transportation system is, and what aspects of characters it should have. This is a fundamental work for applying resilience to practice.
\end{abstract}

\section{Introduction}

Transportation system is a crucial section of the city. In modern society almost all the human activities should rely on transportation systems. However, our transportation system is always exposed to the risks of all kinds of disruptions. These disruptions can come from natural disasters such as earthquake, hurricane, flood, tsunami and so on, or from man-made hazards just as terrorist attack, group events, strike, and system breakdown caused by human error operations or poor management. All these disruptions can brings huge economic losses to the society.

The Kobe earthquake in Japan 1995 resulted in a $\$ 50$ billon loss main caused by the consequential ships diversion [1]. The workers' strike in the west coast of US 2002 caused \$2 billion loss per day because of the transportation service shutdown [1]. The terrorist attack in London metro 2005 reduced 9 million personal travels in the following two weeks [2].Through the above examples we can find that the main source of loss is often not the detriment itself the accidents bring directly, but the consequence caused by the following service shutdown. I.e. the failure of service-providing result from incidents raised much more extensive loss to the whole society.

Responding to this, the concept of resilience was introduced into the area since it concerned about the performance of system under disruptions. Resilience was first studied as a system property in ecology area by C.S. Holling, who initially defined it as the ability of ecological systems to absorb changes of environment variables and still persist [3]. To give a general definition, resilience refers to a system's ability to accommodate variable and unexpected conditions without catastrophic failure, or "the capacity to absorb shocks gracefully" [4]. Since then, the concept of resilience was broadly applied to the field of machinery, psychology, Engineering and economics etc.

Resilience has been researched in the field of transportation by quite a number of scholars as well. Because resilience is a subjective concept of man-made, different researchers have different understand about it and thus have different definitions to identify it. What a resiliency transportation system should be, and what kind of capabilities it should has, they have given diverse explanations.

If managers want to promote transportation system's resilience to avoid potential loss, a list of exact characters of resilience must be clearly defined first. This paper took a summative review of studies on transportation resilience, and then integrated the basic elements and main aspects of 
transportation resilience on the basis of previous researches. This can provide a valuable reference for the following researchers and practitioners.

\section{Comparison of resilience definitions in Transportation area: the core of resilience}

Since the concept of resilience was applied in various areas, and in transportation area it also was borrowed in, there were as many as hundreds of expressions about resilience's definition. In Webster's Dictionary, resilience is defined as "the ability to become strong, healthy, or successful again after something bad happens", or "the ability of something to return to its original shape after it has been pulled, stretched, pressed, bent, etc.” This can be considered as a common source of derived meanings in different research areas. In spite of the distinction of application objects, most definitions of different areas are largely identical and with minor differences. Therefore it may be worthless to take finely discrimination on those definitions literally. It is more important to dig the key elements behind it within a certain circumstance. This paper just concerns about what definitions were used in transportation-related studies, in order to clarify the key elements of resilience in the transportation systems.

Here list the expressions used by previous transportation-related studies in Table 1. Taking a comparison of these definitions in the table, we found that among them there are the same factors as well as different parts.

The objects of these studies are all transportation systems. Some of them gave a specified sub-system like marine transport, or freight transport, and some referred to the whole generalized transportation system. On the level of concept structuring, it is unnecessary to distinguish the sub-systems because the distinction of them is not to be concerned. (In evaluation or application, it may be indispensable.)

These definitions both give a circumstance that the system is under a shock condition ("disturbance", “disaster", “attack”). It is in accord with the real intention of resilienceperformance of system under disruptions.

The biggest difference between them is the verbs they used to describe the system's actions. The word "absorb" has appeared for 3 times, and "maintain" 3 times, "resist" "against" "cope with" each for 1 time. Obviously they are expressing the same meaning. Otherwise, the word "recover(y)" appeared for 4 times, as well the synonym "return", "restore” and "bounce back".

When talking about "absorb" or "resist" on the context of transportation system, there should be a hidden meaning behind it, because one cannot scientifically clarify what is "resist" like and what is the contrary. That hidden meaning should be the service level. Service level is the final criteria to judge if it effectively "resist” or "absorb" or "maintain”. For the verbs "recover(y)" and "return” etc., the criteria is the same. So, it can be inferred almost all the researchers agree that resilience contains two main aspects of characters, one is ability to maintain the service level, and the other is ability to recover service level.

To make a Summary, the circumstance of resilience is an adverse condition of disruptions; the core of transportation resilience is the service level of system, and its two basic elements is the system performance on maintaining and recovery.

Moreover, part of definitions mentioned another restrictive condition_-limited time frame for recovery (or similar statements as "quickly" and "recover speed"). Besides, one of these definitions point out "the amount of outside assistance required for restoration". The timeliness and resourcefulness of recovery may be attributes of resilience.

Table 1. Definitions of Resilience used in transportation area

\begin{tabular}{|l|l|l|}
\hline Definition of resilience & Source & Research Object \\
\hline $\begin{array}{l}\text { The ability of the system to absorb shock as well as } \\
\text { to recover from a disruption so that it can return back } \\
\text { to its original service delivery levels or close to it } \\
\text { [1]. }\end{array}$ & $\begin{array}{l}\text { Mayada Omer, Ali } \\
\text { Mostashari etc. (2012) }\end{array}$ & $\begin{array}{l}\text { Maritime } \\
\text { transportation } \\
\text { system }\end{array}$ \\
\hline A function of system's vulnerability against & Mo Mansouri, & Maritime \\
\hline
\end{tabular}




\begin{tabular}{|c|c|c|}
\hline $\begin{array}{l}\text { potential disruption, and its adaptive capacity in } \\
\text { recovering to an acceptable level of service within a } \\
\text { reasonable time frame after being affected by } \\
\text { disruption [5]. }\end{array}$ & $\begin{array}{l}\text { Roshanak Nilchiani } \\
\text { etc.(2009) }\end{array}$ & $\begin{array}{l}\text { Infrastructure and } \\
\text { Transportation } \\
\text { Systems }\end{array}$ \\
\hline $\begin{array}{l}\text { Capability of a system to provide and maintain an } \\
\text { acceptable level of service in the face of major } \\
\text { changes or disruptions to the environment [6]. }\end{array}$ & $\begin{array}{l}\text { Mo Mansouri, } \\
\text { Roshanak Nilchiani } \\
\text { etc. (2010) }\end{array}$ & $\begin{array}{l}\text { Port infrastructure } \\
\text { systems }\end{array}$ \\
\hline $\begin{array}{l}\text { The ability for the system to maintain its } \\
\text { demonstrated level of service or to restore itself to } \\
\text { that level of service in specified time frame [7]. }\end{array}$ & $\begin{array}{l}\text { Nayel Urena Serulle, } \\
\text { Kevin Heaslip etc. } \\
\text { (2011) }\end{array}$ & $\begin{array}{l}\text { Transportation } \\
\text { Network }\end{array}$ \\
\hline $\begin{array}{l}\text { The ability for a transportation network to absorb } \\
\text { disruptive events gracefully and return itself to a } \\
\text { level of service equal to or greater than the } \\
\text { pre-disruption level of service within a reasonable } \\
\text { time frame [8]. }\end{array}$ & $\begin{array}{l}\text { Derek Freckleton, } \\
\text { Kevin Heaslip etc. } \\
\text { (2012) }\end{array}$ & $\begin{array}{l}\text { Transportation } \\
\text { Networks }\end{array}$ \\
\hline $\begin{array}{l}\text { Both the network's inherent ability to cope with } \\
\text { disruption via its topological and operational } \\
\text { attributes and potential actions that can be taken in } \\
\text { the immediate aftermath of a disruption or disaster } \\
\text { event [9]. }\end{array}$ & $\begin{array}{l}\text { Elise Miller-Hooks, } \\
\text { Xiaodong Zhang etc. } \\
\text { (2012) }\end{array}$ & $\begin{array}{l}\text { Freight } \\
\text { transportation } \\
\text { networks }\end{array}$ \\
\hline $\begin{array}{l}\text { A network's capability to resist and recover from a } \\
\text { disruption or disaster [10]. }\end{array}$ & $\begin{array}{l}\text { Lichun Chen, Elise } \\
\text { Miller-Hooks. (2012) }\end{array}$ & $\begin{array}{l}\text { Intermodal } \\
\text { Freight Transport }\end{array}$ \\
\hline $\begin{array}{l}\text { The ability of a system to return to a stable state } \\
\text { following a strong perturbation caused by failure, } \\
\text { disaster or attack [11]. }\end{array}$ & $\begin{array}{l}\text { W. H. Ip, Dingwei } \\
\text { Wang. (2011) }\end{array}$ & $\begin{array}{l}\text { Transportation } \\
\text { Networks }\end{array}$ \\
\hline $\begin{array}{l}\text { A characteristic that indicates system performance } \\
\text { under unusual conditions, recovery speed, and the } \\
\text { amount of outside assistance required for restoration } \\
\text { to its original functional state [12]. }\end{array}$ & $\begin{array}{l}\text { Pamela M. } \\
\text { Murray-Tuite. (2006) }\end{array}$ & $\begin{array}{l}\text { Transportation } \\
\text { network }\end{array}$ \\
\hline $\begin{array}{l}\text { The capacity to absorb the effects of a disruption and } \\
\text { to quickly return to normal operating levels [13]. }\end{array}$ & $\begin{array}{l}\text { T. M. Adams, K. R. } \\
\text { Bekkem etc. (2012) }\end{array}$ & $\begin{array}{l}\text { Transportation } \\
\text { network }\end{array}$ \\
\hline $\begin{array}{l}\text { The ability of a system to maintain function and to } \\
\text { "bounce back" quickly from a disturbance [2]. }\end{array}$ & $\begin{array}{l}\text { Andrew Cox, Fynnwin } \\
\text { Prager etc. (2010) }\end{array}$ & $\begin{array}{l}\text { Passenger } \\
\text { Transport }\end{array}$ \\
\hline
\end{tabular}

\section{Integration of resilience connotations in transportation area: the key attributes of resilience}

We've learned from above the core of resilience is to maintain and recover service under disruptions. After that, it is also importation to specify the connotations of resilience. We should know what the attributes a transportation resilient system should include in order to maintain/recover its service effectively.

Some scholars have explored its connotations from various perspectives. They developed dozens of principles (or key factors) that a resiliency transportation system should have, with different dimensions classification.

Mayada Omer etc. (2010) proposed the two elements that need to be addressed in order to achieve resiliency in systems are vulnerability and adaptive capacity. To reduce the vulnerability, the schemes of the system include redundancy, diversity, hardening, capacity tolerance and modularity. To increase the adaptive capacity, the schemes include proper resources allocation, contingency preparation, collaboration and system cognition. [1]

Nayel Urena Serulle etc. (2011) classified resiliency to two big dimensions "Infrastructure resiliency" and "user resiliency”. The former includes network availability and network accessibility, and the latter includes traveler perception and transportation cost. [7] 
Pamela M. Murray-Tuite (2006) developed ten properties of resilience system. They were redundancy, diversity, efficiency, autonomous components, strength, adaptability, collaboration, mobility, safety, and the ability to recover quickly. [12]

Andrew Cox etc. (2011) defined two categories of resilience strategies of transportation system: static and dynamic. Static strategies conclude conservation, input substitution, inventories, excess capacity, relocation, resource unimportance, import substitution, export substitution, technological change, production recapture, and logistics refinement. Dynamic resilience strategies include removing operating impediments, management effectiveness, and speeding restoration. [2]

Victoria Transport Policy Institute (2014) developed eight strategies that can increase Resilience of transportation system. They were diversity, redundancy and connectivity, increasing design/construction standards, problem identification, communication, and resources prioritization. [14]

Table 2. Integrated Attributes of Resilience

\begin{tabular}{|c|c|c|c|}
\hline Target & Dimensions & Attributes & Ability \\
\hline \multirow{6}{*}{$\begin{array}{l}\text { Maintain the } \\
\text { service level }\end{array}$} & \multirow{4}{*}{ Robustness } & Hardening & $\begin{array}{l}\text { Increase design and construction standards to } \\
\text { enable system to withstand extreme } \\
\text { conditions. }\end{array}$ \\
\hline & & Modularity & $\begin{array}{l}\text { The modules were independent so that the } \\
\text { one damaged would not influence the work } \\
\text { of others, and also can be restored easily. }\end{array}$ \\
\hline & & $\begin{array}{l}\text { Network } \\
\text { Management }\end{array}$ & $\begin{array}{l}\text { The management, communication and } \\
\text { collaboration were well organized to be } \\
\text { prepared for contingency. }\end{array}$ \\
\hline & & $\begin{array}{l}\text { Service } \\
\text { performance }\end{array}$ & $\begin{array}{l}\text { The traffic speed decrease, travel time delay } \\
\text { and cost increase are acceptable after } \\
\text { disruptions. }\end{array}$ \\
\hline & \multirow[b]{2}{*}{ Redundancy } & $\begin{array}{l}\text { Capacity } \\
\text { tolerance }\end{array}$ & $\begin{array}{l}\text { System should have capacity that would meet } \\
\text { the service demand beyond usual level. }\end{array}$ \\
\hline & & $\begin{array}{l}\text { Alternative } \\
\text { choices }\end{array}$ & $\begin{array}{l}\text { When the initial system breakdown, one can } \\
\text { easily choose the substitute system } \\
\text { (mode/rote) to achieve his travel. }\end{array}$ \\
\hline \multirow{4}{*}{$\begin{array}{l}\text { Recover } \\
\text { service level }\end{array}$} & \multirow{4}{*}{ Recovery } & $\begin{array}{l}\text { Resource } \\
\text { accessibility }\end{array}$ & $\begin{array}{l}\text { The resources need to recover the damaged } \\
\text { system have a high priority to get. }\end{array}$ \\
\hline & & $\begin{array}{l}\text { Recovery } \\
\text { timely }\end{array}$ & $\begin{array}{l}\text { Recovery activities can be conduct timely } \\
\text { after disruptions. }\end{array}$ \\
\hline & & $\begin{array}{l}\text { Recovery } \\
\text { effective }\end{array}$ & $\begin{array}{l}\text { The service level such as travel time, traffic } \\
\text { speed and vehicle flow return to normal. }\end{array}$ \\
\hline & & Recovery cost & $\begin{array}{l}\text { The cost of Recovery activities are } \\
\text { acceptable. }\end{array}$ \\
\hline
\end{tabular}

Because a large amount of the attributes mentioned in previous studies have a similar or identical meaning, here we do not list the every detailed description of them. This paper took a summary and integration of them and gave a unified specification in Table 2.

These attributes were integrated into three dimensions as Robustness, Redundancy and Recovery. Robustness concerns about the resistance ability of system when suffering disruptions. Redundancy concerns about the system can provide spare service capacity when some components were damaged. In accordance with the core of resilience proposed last part, Robustness and Redundancy concerns about the ability of maintain service level. Recovery concerns about the ability and effect of system recover the service level. 
Among these attributes, some are kind of pre-disruption resiliency strategies such as "hardening", "network management" etc., and some are the post-disruption strategies like "recovery timely". "Service performance" attribute reflect the system performance of pre-recovery activity, while "Recovery effective" reflect the performance of post-recovery activity.

Specifying these attributes of resilience is a crucial pre-work for evaluation and implementation. If we want to promote a system's resiliency, we must first evaluate it; and if we want evaluate, we must first develop criteria and measure metrics on the basis of these attributes.

\section{Summary}

Resilience as a crucial character of transportation system has attracted more and more attention from scholars and managers. However the different understand of its definition and connotation brings obstacle for practitioners to promote the transportation resilience. This paper gave a summative review of the definition and connotation of transportation resilience of previous researches, and then based on which generated a list of integrated attributes of transportation resilience. It can help following researchers take a comprehensive perspective on transportation resilience, and it is the fundamental work to the future research of evaluation or implement.

The limit of this paper lies on that it is totally summarized by others' precedent study. However resilience is a subjective concept of man-made which is just a rising research topic, the Summary of this paper may still cannot absolutely cover the full meaning of resilience. It need more exploratory studies.

\section{References}

[1] Mayada Omer, Ali Mostashari, Roshanak Nilchiani and Mo Mansouri: A framework for assessing resiliency of maritime, Maritime Policy \& Management, Vol.39 (2012), No.7, p685-703

[2] Andrew Cox, Fynnwin Prager and Adam Rose: Transportation security and the role of resilience: A foundation for operational metrics, Transport Policy, Vol.18 (2011), p307-317

[3] C. S. Holling, resilience and stability of ecological systems, Annual Review of Ecology and Systematics, Vol.4, p. 1-23

[4] Harold Foster, Resilience Theory and System Evaluation, Verification and Validation of Complex Systems: Human Factor Issues, Vol.110, p35-60

[5] Mo Mansouri, Roshanak Nilchiani and Ali Mostashari: A Risk Management-Based Decision Analysis Framework for Resilience in Maritime Infrastructure and Transportation Systems, 3rd Annual IEEE International Systems Conference, 2009

[6] Mo Mansouri, Roshanak Nilchiani and Ali Mostashari: A policy making framework for resilient port infrastructure systems, Marine Policy, Vol. 34(2010), p1125-1134

[7] Nayel Urena Serulle, Kevin Heaslip, Brandon Brady, William C. Louisell and John Collura: A Case Study of Transportation Network Resiliency of Santo Domingo, Dominican Republic, TRB Annual Meeting, 2011

[8] Derek Freckleton, Kevin Heaslip, William Louisell and John Collura: Evaluation of Resiliency of Transportation Networks After Disasters, Transportation Research Record: Journal of the Transportation Research Board, No. 2284(2012), p109-116

[9] Elise Miller-Hooks, Xiaodong Zhang and Reza Faturechi: Measuring and maximizing resilience of freight transportation networks: Computers \&Operations Research, Vol. 39(2012), p1633-1643

[10]Lichun Chen and Elise Miller-Hooks: Resilience: An Indicator of Recovery Capability in Intermodal Freight Transport, Transportation Science, Vol. 46, No. 1, (2012), p109-123 
[11]W. H. Ip and Dingwei Wang: Resilience and Friability of Transportation Networks: Evaluation, Analysis and Optimization, IEEE Systems Journal, VOL. 5, NO. 2, (2011), p189-198

[12] Pamela M. Murray-Tuite: A comparison of transportation network resilience under simulated system optimum and user equilibrium conditions, Proceedings of the 2006 Winter Simulation Conference, p1398-1405

[13]Teresa M. Adams, Kaushik R. Bekkem and Edwin J. Toledo-Durán: Freight Resilience Measures, Journal of Transportation Engineering, Vol. 138, No. 11 (2012), p1403-1409

[14] Victoria Transport Policy Institute: Evaluating Transportation Resilience: Evaluating the Transportation System's Ability to Accommodate Diverse, Variable and Unexpected Demands with Minimal Risk. http://www.vtpi.org/tdm/tdm88.htm 